\title{
Isotopic Analysis of
}

Uranium in Natural Waters

\section{by Alpha Spectrometry}

GEOLOGICAL SURVEY WATER-SUPPLY PAPER 1696-F

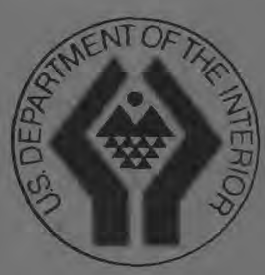




\section{Isotopic Analysis of}

\section{Uraniumin Natural Waters}

by Alpha Spectrometry

By KENNETH W. EDWARDS

R A D I CHEM I C A L A N A Y I S OF W A T E R

GEOLOGICAL SURVEY WATER-SUPPLY PAPER 1696-F

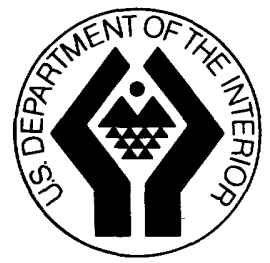


UNITED STATES DEPARTMENT OF THE INTERIOR

STEWART L. UDALL, Secretary

GEOLOGIGAL SURVEY

William T. Pecora, Director

For sale by the Superintendent of Documents, U.S. Government Printing Office Washington, D.C. 20402 - Price 15 cents (paper cover) 


\section{CONTENTS}

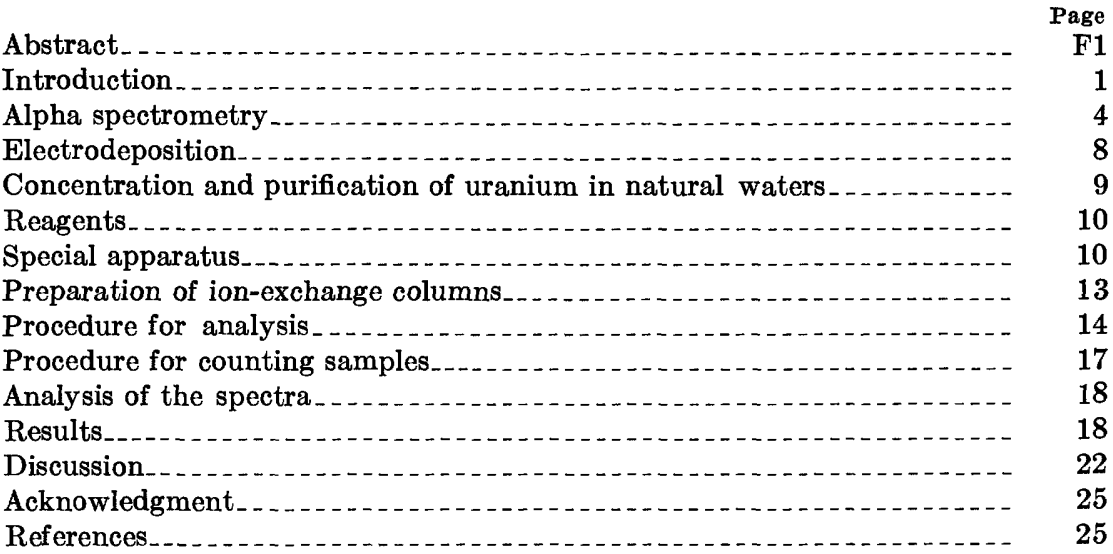

\section{ILLUSTRATIONS}

Figure 1. Graph showing alpha spectrum of uranium from Clear Creek, near Golden, Colo.

2. Schematic diagram of alpha spectrometer..... 7

3. Photograph of alpha spectrometer.

4. Sketch of ion-exchange column

5. Photograph of equipment for electrodeposition

6. Graph showing effect of source thickness on resolution of uranium alpha spectra............................... 20

\section{TABLES}

TABLE 1. Relative statistical error in $U^{234 / U^{23 B}}$ ratios for various inter-

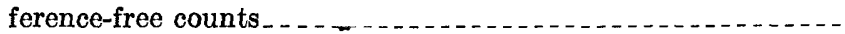

2. Absolute statistical error in $U^{234} / U^{238}$ ratios for various interference-free counts . . .

3. Energies of alpha particles emitted by naturally occurring

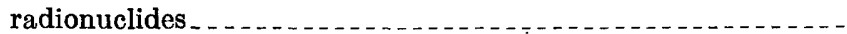

4. Maximum, minimum, and recommended sample volumes for isotopic uranium analyses....................................

5. Recovery of uranium standards carried through entire chemical and electrochemical procedure . . . 
TABLE 6. Isotopic uranium blanks run on distilled water samples

7. Efficiency and resolution as a function of number of counts.

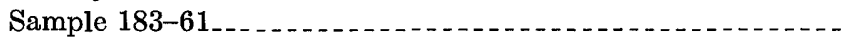

8. $\mathrm{U}^{234} / \mathrm{U}^{238}$ activity ratios as determined by mass spectrometry and alpha spectrometry

9. $\mathrm{U}^{234} / \mathrm{U}^{238}$ ratios of eastern slope streams in Colorado 


\title{
RADIOCHEMICAL ANALYSIS OF WATER
}

\section{ISOTOPIC ANALYSIS OF URANIUM IN NATURAL WATERS BY ALPHA SPECTROMETRY}

\author{
By Kenneth W. Edwards
}

\begin{abstract}
A method is described for the determination of $\mathrm{U}^{234} / \mathrm{U}^{238}$ activity ratios for uranium present in natural waters. The uranium is coprecipitated from solution with aluminum phosphate, extracted into ethyl acetate, further purified by ion exchange, and finally electroplated on a titanium disc for counting. The individual isotopes are determined by measurement of the alpha-particle energy spectrum using a high resolution low-background alpha spectrometer. Overall chemical recovery of about 90 percent and a counting efficiency of 25 percent allow analyses of water samples containing as little as $0.10 \mu \mathrm{g} / 1$ of uranium. The accuracy of the method is limited, on most samples, primarily by counting statistics.
\end{abstract}

\section{INTRODUCTION}

Three isotopes of uranium occur in nature. These isotopes have atomic masses of 238,235 , and 234 . $\mathrm{U}^{238}$ is by far the most abundant, accounting for 99.28 weight percent of all natural uranium. $\mathrm{U}^{235}$ accounts for most of the balance ( 0.711 percent), and $U^{234}$ has a very low chemical abundance ( 0.006 percent). In terms of their activities (disintegration rates), however, $\mathrm{U}^{238}$ and $\mathrm{U}^{234}$ are equally abundant, whereas $\mathrm{U}^{235}$ has only 4.6 percent of the abundance of $\mathrm{U}^{238}$.

It is generally accepted that the abundance ratio of $\mathrm{U}^{235}$ to $\mathrm{U}^{238}$ is virtually constant (within 0.1 percent) throughout nature (Atomics, 1964). Each of these isotopes is a parent of a naturally occurring radioactive decay series: $\mathrm{U}^{238}$ is the parent nuclide of the "uranium series," and $\mathrm{U}^{235}$ is the parent of the "actinium series." Since these isotopes bear no genetic relationship to each other, they are expected to be in the same chemical state and in constant ratio everywhere they occur. 
Uranium-234 is not an independently occurring radionuclide, but is rather a third generation decay product of $\mathrm{U}^{238}$.

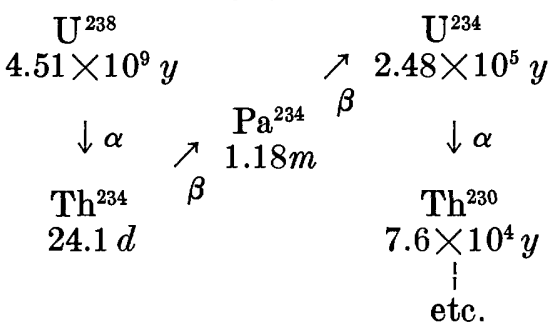

It is evident that, because of this genetic relationship, $\mathrm{U}^{234}$ owes its existence to the parent isotope $\mathrm{U}^{238}$. Furthermore, since the half life of $\mathrm{U}^{234}$ is short with respect to both the half life of $\mathrm{U}^{238}$ and the age of the earth, the total activity (that is, the total number of atoms which decay per unit time) of $U^{234}$ in the earth must be equal to the total activity of $U^{238}$. This follows directly from the laws of radioactive decay and growth.

Despite the large-scale equilibrium between these isotopes, local disequilibria may exist and, in fact, are very common. Numerous studies of uranium isotopes in nature have disclosed substantial disequilibria in natural waters (Chalov and others, 1964; Sakanoue and Hashimoto, 1964; Cherdyntsev and others, 1963; Thurber, 1962; Ancarani and Bettinali, 1960; Isabaev and others, 1960), in soils (Rosholt, Doe, Tatsumoto, 1966; Cherdyntsev and others, 1963), and in a wide variety of rocks and minerals (Cherdyntsev and others, 1965, 1963, 1961; Rosholt, Butler, and others, 1965; Rosholt, Tatsumoto and Dooley, 1965; Syromyatnikov, 1965; Dooley and others, 1964; Rosholt, Harshman, and others, 1964; Sakanoue and Hashimoto, 1964 ; Rosholt, Shields, and others, 1963; Syromyatnikov and Tolmachev, 1962; Thurber, 1962; Isabaev and others, 1960). These disequilibria arise as a result of the physical and chemical changes which occur in the decay process. The energy released in the alpha decay of $\mathrm{U}^{238}$ to $\mathrm{Th}^{234}$ provides sufficient recoil energy to the atom to cause the breaking of chemical bonds. The "hot" atoms may immediately recombine with the matrix material or may be transported by water, with which they come in contact, to variable distances from the sites of the original decay process. In addition to the physical recoil process, $\mathrm{Th}^{234}$ and $\mathrm{Pa}^{234}$ are chemically different from uranium, and chemical differentiation may occur. Formation of $\mathrm{U}^{234}$ in a higher oxidation state than the surrounding $\mathrm{U}^{238}$ atoms may also occur as a natural consequence of the mechanics of the decay process. Chemical separation of isotopes is obviously possible when their oxidation states are not the same. These phenomena have been discussed by a number of investigators (Cherdyntsev and others, 1965, 1963, 1961; Rosholt, 
Butler, and others, 1965; Rosholt, Tatsumoto, and Dooley, 1965; Syromyatnikov, 1965; Chalov and others, 1964; Rosholt, Harshman, and others, 1964; Rosholt, Shields, and others, 1963).

Uranium occurs in low concentrations in many natural waters. Sea water has an average uranium content of about $2 \mu \mathrm{g} / \mathrm{l}$ (micrograms per liter) (Katz and Rabinowitch, 1951, p. 71), and most fresh waters have concentrations below $10 \mu \mathrm{g} / 1$ (Barker and others, 1965). Some ground-water sources, however, have uranium concentrations as high as several milligrams per liter. The present investigation was initiated to establish the methodology, sensitivity, and accuracy with which the relative abundances of uranium-238 and uranium-234 can be determined in natural water. The method herein reported is intended primarily for analyses of natural waters, but it may also be used on other aqueous systems which are not appreciably enriched in uranium235. The method is based on spectral analysis of the alpha particles emitted by uranium isolated from the water sample. The number of counts necessary to obtain a desired accuracy in the $\mathrm{U}^{234} / \mathrm{U}^{238}$ ratio under interference-free conditions is shown for various ratios in tables 1 and 2 . Because of the low specific activity of uranium, 0.739 dis-

$\mathrm{T}_{\mathrm{ABLE}}$ 1.-Relative statistical error in $\mathrm{U}^{234} / \mathrm{U}^{238}$ ratios for various interference-free counts

\begin{tabular}{|c|c|c|c|c|c|c|c|c|c|}
\hline \multirow{2}{*}{$\begin{array}{l}\text { Total counts } \\
\left(\mathrm{U}^{234}+\mathrm{U}^{2238}\right)\end{array}$} & \multicolumn{9}{|c|}{ Relative standard deviation in ratio for $\mathrm{U}^{234} / \mathrm{U}^{233}$ values of- } \\
\hline & 0.4 & 0.6 & 0.8 & 1.0 & 1.2 & 1.4 & 1.6 & 1.8 & 2.0 \\
\hline $\begin{array}{l}200 \ldots \\
300 \\
400 \\
500 \\
600\end{array}$ & $\begin{array}{r}0.157 \\
.128 \\
.110 \\
.099 \\
.090\end{array}$ & $\begin{array}{r}0.146 \\
.119 \\
.103 \\
.092 \\
.084\end{array}$ & $\begin{array}{r}0.142 \\
.116 \\
.101 \\
.090 \\
.082\end{array}$ & $\begin{array}{l}0.141 \\
.115 \\
.100 \\
.089 \\
.082\end{array}$ & $\begin{array}{r}0.142 \\
.116 \\
.101 \\
.090 \\
.082\end{array}$ & $\begin{array}{r}0.144 \\
.117 \\
.101 \\
.091 \\
.083\end{array}$ & $\begin{array}{r}0.145 \\
.118 \\
.103 \\
.092 \\
.084\end{array}$ & $\begin{array}{r}0.148 \\
.120 \\
.104 \\
.093 \\
.085\end{array}$ & $\begin{array}{r}0.150 \\
.122 \\
.106 \\
.095 \\
.087\end{array}$ \\
\hline $\begin{array}{l}700 \\
800 \\
900 \\
1,000 \\
1,200\end{array}$ & $\begin{array}{l}.084 \\
.078 \\
.074 \\
.070 \\
.064\end{array}$ & $\begin{array}{l}.078 \\
.073 \\
.069 \\
.065 \\
.060\end{array}$ & $\begin{array}{l}.076 \\
.071 \\
.067 \\
.064 \\
.058\end{array}$ & $\begin{array}{l}.076 \\
.071 \\
.067 \\
.063 \\
.058\end{array}$ & $\begin{array}{l}.076 \\
.071 \\
.067 \\
.063 \\
.058\end{array}$ & $\begin{array}{l}.077 \\
.072 \\
.068 \\
.064 \\
.059\end{array}$ & $\begin{array}{l}.078 \\
.073 \\
.069 \\
.065 \\
.059\end{array}$ & $\begin{array}{l}.079 \\
.074 \\
.070 \\
.066 \\
.060\end{array}$ & $\begin{array}{l}.080 \\
.075 \\
.071 \\
.067 \\
.061\end{array}$ \\
\hline $\begin{array}{l}1,500 \\
2,000 \\
2,500 \\
3,000 \\
4,000\end{array}$ & $\begin{array}{l}.057 \\
.050 \\
.044 \\
.040 \\
.035\end{array}$ & $\begin{array}{l}.053 \\
.046 \\
.041 \\
.038 \\
.033\end{array}$ & $\begin{array}{l}.052 \\
.045 \\
.040 \\
.037 \\
.032\end{array}$ & $\begin{array}{l}.052 \\
.045 \\
.040 \\
.037 \\
.032\end{array}$ & $\begin{array}{l}.052 \\
.045 \\
.040 \\
.037 \\
.032\end{array}$ & $\begin{array}{l}.052 \\
.045 \\
.041 \\
.037 \\
.032\end{array}$ & $\begin{array}{l}.053 \\
.046 \\
.041 \\
.038 \\
.033\end{array}$ & $\begin{array}{l}.054 \\
.047 \\
.042 \\
.038 \\
.033\end{array}$ & $\begin{array}{l}.055 \\
.047 \\
.042 \\
.039 \\
.033\end{array}$ \\
\hline $\begin{array}{l}5,000 \\
6,000 \\
8,000 \\
10,000 \\
12,000\end{array}$ & $\begin{array}{l}.031 \\
.029 \\
.025 \\
.022 \\
.020\end{array}$ & $\begin{array}{l}.029 \\
.027 \\
.023 \\
.021 \\
.019\end{array}$ & $\begin{array}{l}.029 \\
.026 \\
.023 \\
.020 \\
.018\end{array}$ & $\begin{array}{l}.028 \\
.026 \\
.022 \\
.020 \\
.018\end{array}$ & $\begin{array}{l}.028 \\
.026 \\
.022 \\
.020 \\
.018\end{array}$ & $\begin{array}{l}.029 \\
.026 \\
.023 \\
.020 \\
.019\end{array}$ & $\begin{array}{l}.029 \\
.027 \\
.023 \\
.021 \\
.019\end{array}$ & $\begin{array}{l}.030 \\
.027 \\
.023 \\
.021 \\
.019\end{array}$ & $\begin{array}{l}.030 \\
.027 \\
.024 \\
.021 \\
.019\end{array}$ \\
\hline $\begin{array}{l}15,000 \\
20,000 \\
30,000_{-} \\
40,000_{-} \\
50,000_{-}\end{array}$ & $\begin{array}{l}.018 \\
.016 \\
.013 \\
.011 \\
.010\end{array}$ & $\begin{array}{l}.017 \\
.015 \\
.012 \\
.010 \\
.009\end{array}$ & $\begin{array}{l}.016 \\
.014 \\
.012 \\
.010 \\
.009\end{array}$ & $\begin{array}{l}.016 \\
.014 \\
.012 \\
.010 \\
.009\end{array}$ & $\begin{array}{l}.016 \\
.014 \\
.012 \\
.010 \\
.009\end{array}$ & $\begin{array}{l}.017 \\
.014 \\
.012 \\
.010 \\
.009\end{array}$ & $\begin{array}{l}.017 \\
.015 \\
.012 \\
.010 \\
.009\end{array}$ & $\begin{array}{l}.017 \\
.015 \\
.012 \\
.010 \\
.009\end{array}$ & $\begin{array}{l}.017 \\
.015 \\
.012 \\
.011 \\
.010\end{array}$ \\
\hline
\end{tabular}


TABLE 2.-Absolute statistical error in $\mathrm{U}^{234} / \mathrm{U}^{238}$ ratios for various interferencefree counts

\begin{tabular}{|c|c|c|c|c|c|c|c|c|c|}
\hline \multirow{2}{*}{$\begin{array}{l}\text { Total counts } \\
\left(\mathrm{U}^{234}+\mathrm{U}^{238}\right)\end{array}$} & \multicolumn{9}{|c|}{ Absolute standard deviation in ratio for $\mathrm{U}^{234} / \mathrm{U}^{228}$ values of- } \\
\hline & 0.4 & 0.6 & 0.8 & 1.0 & 1.2 & 1.4 & 1.6 & 1.8 & 2.0 \\
\hline $\begin{array}{l}200 \\
300 \\
400 \\
500 \\
600\end{array}$ & $\begin{array}{l}0.063 \\
.051 \\
.044 \\
.040 \\
.036\end{array}$ & $\begin{array}{r}0.088 \\
.071 \\
.062 \\
.055 \\
.050\end{array}$ & $\begin{array}{l}0.114 \\
.093 \\
.081 \\
.072 \\
.066\end{array}$ & $\begin{array}{l}0.141 \\
.115 \\
.100 \\
.089 \\
.082\end{array}$ & $\begin{array}{r}0.170 \\
.139 \\
.121 \\
.108 \\
.098\end{array}$ & $\begin{array}{l}0.202 \\
.164 \\
.141 \\
.127 \\
.116\end{array}$ & $\begin{array}{l}0.232 \\
.189 \\
.165 \\
.147 \\
.134\end{array}$ & $\begin{array}{r}0.266 \\
.216 \\
.187 \\
.167 \\
.153\end{array}$ & $\begin{array}{r}0.300 \\
.244 \\
.212 \\
.190 \\
.174\end{array}$ \\
\hline $\begin{array}{l}700 \\
800 \\
900 \\
1,000 \\
1,200\end{array}$ & $\begin{array}{l}.034 \\
.031 \\
.030 \\
.028 \\
.026\end{array}$ & $\begin{array}{l}047 \\
.044 \\
.041 \\
.039 \\
.036\end{array}$ & $\begin{array}{l}.061 \\
.057 \\
.054 \\
.051 \\
.046\end{array}$ & $\begin{array}{l}.076 \\
.071 \\
.067 \\
.063 \\
.058\end{array}$ & $\begin{array}{l}.091 \\
.085 \\
.080 \\
.076 \\
.070\end{array}$ & $\begin{array}{l}.108 \\
.101 \\
.095 \\
.090 \\
.083\end{array}$ & $\begin{array}{l}.125 \\
.117 \\
.110 \\
.104 \\
.094\end{array}$ & $\begin{array}{l}.142 \\
.133 \\
.126 \\
.119 \\
.108\end{array}$ & $\begin{array}{l}13 \\
.12\end{array}$ \\
\hline $\begin{array}{l}1,500 \\
2,000 \\
2,500 \\
3,000 \\
4,000\end{array}$ & $\begin{array}{l}.023 \\
.020 \\
.018 \\
.016 \\
.014\end{array}$ & $\begin{array}{l}.032 \\
.028 \\
.025 \\
.023 \\
.020\end{array}$ & $\begin{array}{l}.042 \\
.036 \\
.032 \\
.030 \\
.026\end{array}$ & $\begin{array}{l}.052 \\
.045 \\
.040 \\
.037 \\
.032\end{array}$ & $\begin{array}{l}.062 \\
.054 \\
.048 \\
.044 \\
.038\end{array}$ & $\begin{array}{l}.073 \\
.063 \\
.057 \\
.052 \\
.045\end{array}$ & $\begin{array}{l}.085 \\
.074 \\
.066 \\
.061 \\
.053\end{array}$ & $\begin{array}{l}.097 \\
.085 \\
.076 \\
.068 \\
.059\end{array}$ & $\begin{array}{l}.08 \\
.07 \\
.06\end{array}$ \\
\hline $\begin{array}{l}5,000 \\
6,000 \\
8,000 \\
10,000 \\
12,000\end{array}$ & $\begin{array}{l}.012 \\
.012 \\
.010 \\
.009 \\
.008\end{array}$ & $\begin{array}{l}.017 \\
.016 \\
.014 \\
.013 \\
.011\end{array}$ & $\begin{array}{l}.023 \\
.021 \\
.018 \\
.016 \\
.014\end{array}$ & $\begin{array}{l}.028 \\
.026 \\
.022 \\
.020 \\
.018\end{array}$ & $\begin{array}{l}.034 \\
.031 \\
.026 \\
.024 \\
.022\end{array}$ & $\begin{array}{l}.041 \\
.036 \\
.032 \\
.028 \\
.027\end{array}$ & $\begin{array}{l}.046 \\
.043 \\
.037 \\
.034 \\
.030\end{array}$ & $\begin{array}{l}.054 \\
.049 \\
.041 \\
.038 \\
.034\end{array}$ & $\begin{array}{r}04 \\
.03\end{array}$ \\
\hline $\begin{array}{l}15,000 \\
20,000 \\
30,000 \\
40,000 \\
50,000\end{array}$ & $\begin{array}{l}.007 \\
.006 \\
.005 \\
.004 \\
.004\end{array}$ & $\begin{array}{l}.010 \\
.009 \\
.007 \\
.006 \\
.005\end{array}$ & $\begin{array}{l}.013 \\
.011 \\
.010 \\
.008 \\
.007\end{array}$ & $\begin{array}{l}016 \\
.014 \\
012 \\
.010 \\
.009\end{array}$ & $\begin{array}{l}.019 \\
.017 \\
.014 \\
.012 \\
.011\end{array}$ & $\begin{array}{l}.024 \\
.020 \\
.017 \\
.014 \\
.013\end{array}$ & $\begin{array}{l}.027 \\
.024 \\
.019 \\
.016 \\
.014\end{array}$ & $\begin{array}{l}.031 \\
.027 \\
.022 \\
.018 \\
.016\end{array}$ & $\begin{array}{l}.03 \\
.03 \\
.02 \\
.02 \\
.02\end{array}$ \\
\hline
\end{tabular}

integration per minute of $\mathrm{U}^{238}$ per $\mu \mathrm{g}$, it is evident that it is often necessary to concentrate the uranium from several liters of water from a natural source to make possible a practical determination of the relative isotopic abundances. Principles and procedures of concentrating, electroplating, and counting the uranium isotopes are described in the following sections.

\section{ALPHA SPECTROMETRY}

Alpha particles are emitted from nuclei with discrete energies which are characteristic of the source. A particular nuclide may emit alpha particles of a single discrete energy or of several different energies, depending upon its nuclear properties. In either case, however, the energies of the alpha particles are well defined and may be used to characterize the emitting nuclide. Both qualitative and quantitative analyses may be made by measurements of the alpha energy spectra of suitable sources.

The introduction of semiconductor detectors into the field of nuclear radiation spectrometry has substantially simplified and improved both charged particle and gamma-ray energy spectrum measure- 
ments. This is especially true in alpha spectrometry where silicon surface-barrier semiconductor detectors have the advantages of excellent linearity, stability, and resolution, very low background, fast response, moderate cost, and are easy to use and relatively troublefree. The insensitivity of alpha and beta semiconductor detectors to gamma radiation makes shielding unnecessary in most work. The principle of operation and modern aspects of these detectors are discussed in many publications (Nucleonics, 1964, 1962; Donovan, 1962; Cathey, 1961).

The applicability of alpha spectrometry to quantitative analysis of alpha-emitting nuclides in natural water depends on (a) the concentration, chemistry, and decay characteristics of the nuclides present and on (b) the properties of the detection system.

The decay characteristics of natural alpha emitters are summarized in table 3. Several of these emitters (notably the polonium isotopes)

$\mathrm{T}_{\mathrm{ABLE}}$ 3.-Energies of alpha particles emitted by naturally occurring radionuclides [Data from Strominger and others, 1958]

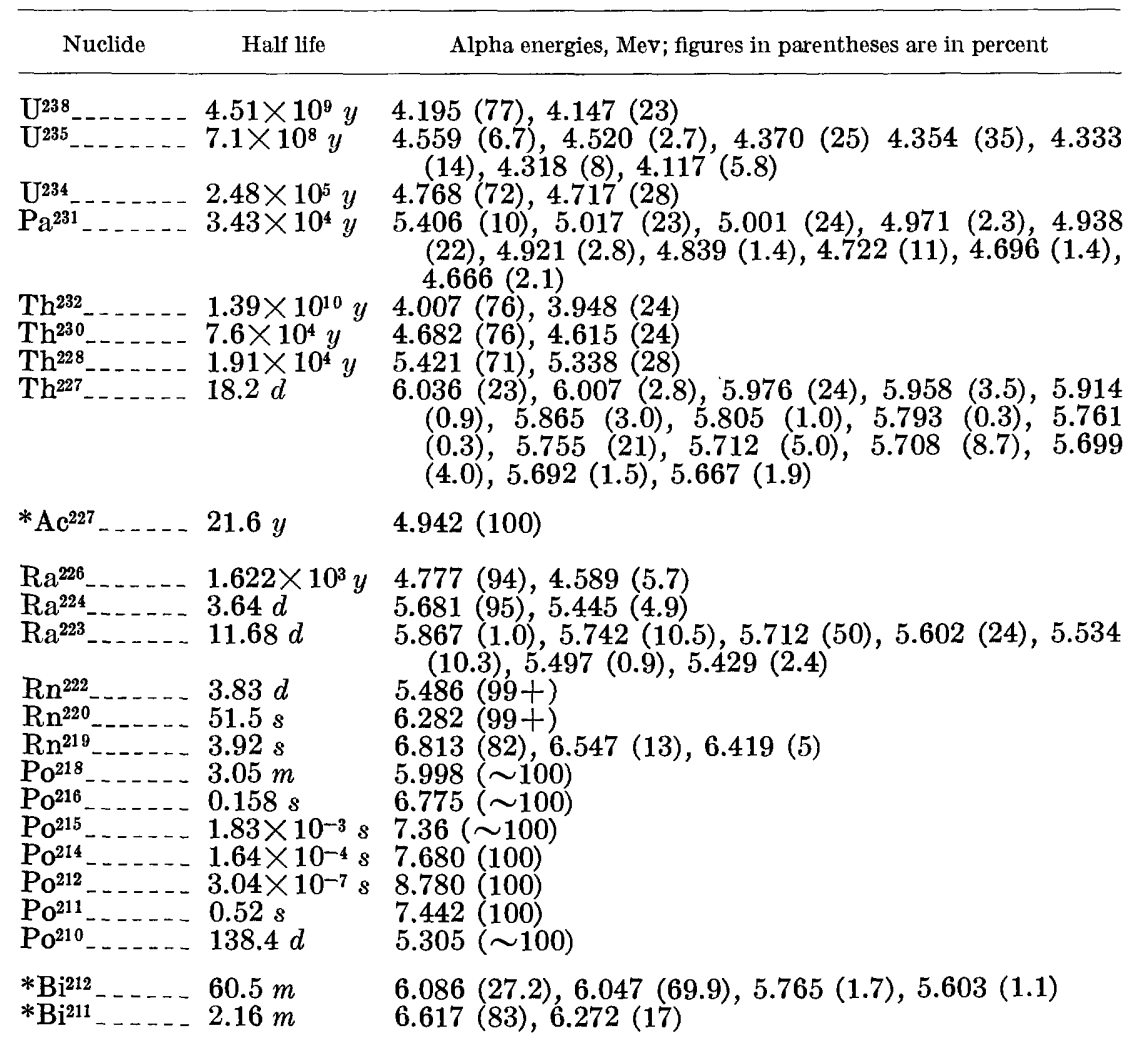

${ }^{*} \mathrm{Ac}^{227}, \mathrm{Bi}^{212}$, and $\mathrm{Bi}^{211}$ decay only $1.2,63.8$, and 99.7 percent, respectively, by alpha emission. The balance of the decay is by beta emission. 
decay with the emission of monoenergetic alpha particles, whereas many others decay with the emission of alpha particles of two or more discrete energies. Since these energies are discrete, the energy spectra of infinitely thin alpha sources deviate from line spectra only due to the limitations of the detection system. Further deviations from line spectra result from partial loss of energy of alpha particles in collisions with atoms within the source, for sources of finite thickness, and in the medium between source and detector. Since all the alpha energies fall within the energy range of 4 to $9 \mathrm{Mev}$ (million electron volts), it is desirable to use samples and detector systems which will afford resolution adequate to avoid or minimize overlap of spectral peaks. Alpha particles lose energy very rapidly in passing through matter, so sources for spectral analysis should be kept as thin as possible and should be counted in a vacuum chamber.

Figure 1 shows the characteristic alpha spectrum of natural uranium. $\mathrm{U}^{238}$ and $\mathrm{U}^{234}$ each emit alpha particles of tiwo distinct, but only slightly separated, energies. As shown in table $3, \mathrm{U}^{238}$ has alpha energies of $4.195 \mathrm{Mev}$ (77 percent) and $4.147 \mathrm{Mev}$ (23 percent). These peaks are not completely resolved, but the minor peak is evidenced by the inflection on the low energy side of the major peak. Similarly, $\mathrm{U}^{234}$ has alpha energies of 4.768 (72 percent) and 4.717 (28 percent) which are not completely resolved. The less abundant

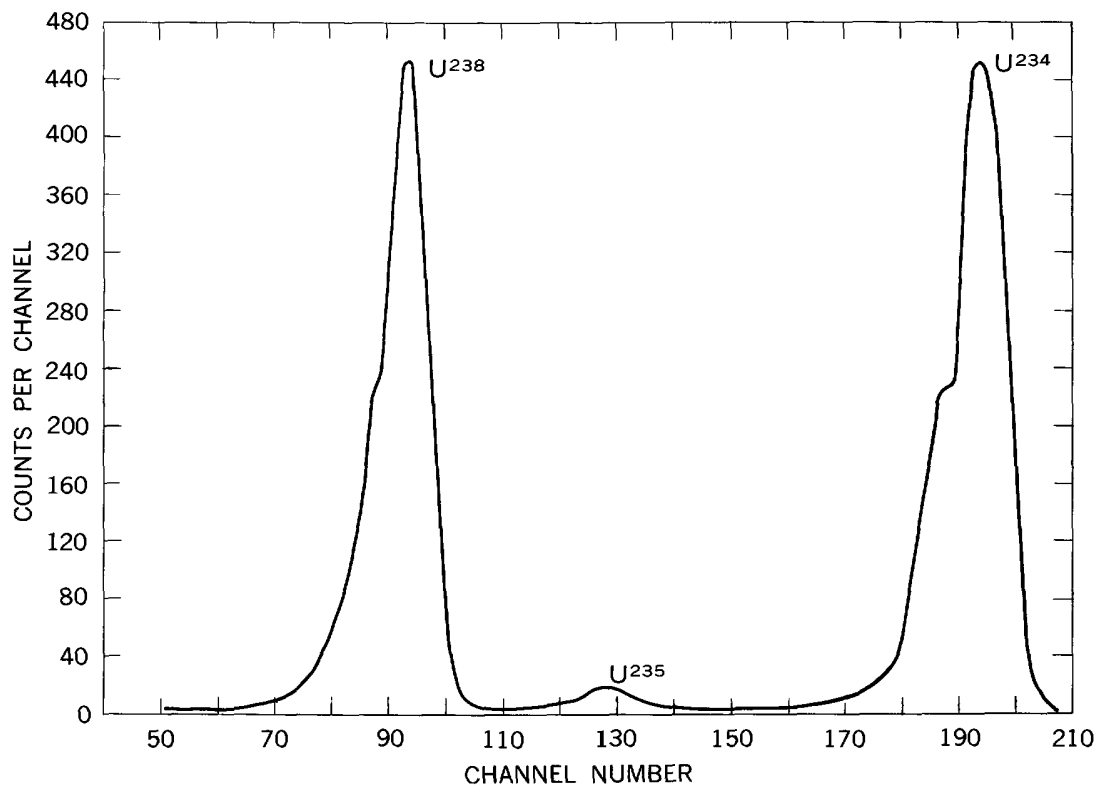

Figure 1.-Alpha spectrum of uranium from Clear Creek at Golden, Colo. Sample collected Mar. 3, 1966. 
(in activity) $\mathrm{U}^{235}$ has many different, energies, but most of these are close together (82 percent 4.32-4.37 Mev).

A spectrum such as figure 1 is obtained by allowing alpha particles to react with matter in such a way as to generate electric pulses which are proportional in current and (or) voltage to the energy of the particle. These pulses are sorted by suitable electronic equipment into a pulse height, or energy, spectrum. Many types of detectors can be used for charged particle spectrometry, but gas ionization chambers or solid-state semiconductor detectors are most suitable. The latter have many advantages as noted above.

The solid-state detectors used are in effect silicon diodes consisting of a very thin sensitive surface of p-type silicon over a much thicker wafer of n-type silicon. A reverse bias of about 50 volts is applied across the diode from a stable power supply. Alpha particles striking the sensitive surface penetrate into the $n$-type layer and produce electron-hole pairs in direct proportion to the energy of the particle. The pairs are accelerated to the electrodes and produce a pulse which is picked up by a charge sensitive preamplifier. The pulse is amplified by a suitable low-noise amplifier and fed into a multichannel pulse height analyzer. The latter is simply a device for sorting the incoming pulses on the basis of their amplitude and storing them in appropriate bins or channels that are linearly related to the energy. After accumulation and storage of the pulses, the memory of the analyzer may be interrogated and the data read out as a spectrum. This spectrum may be in any one of a variety of forms: digital data typed or printed by a parallel printer, punched tape, magnetic tape, visual display on an oscilloscope, or graphical representation on an $X-Y$ plot. A schematic representation of a complete alpha spectrometer is shown in figure 2 . The system used for part of the work presented in this report is shown in figure 3.

Resolution of solid-state detectors is expressed as the ratio of the full width at half maximum (FWHM) of a monoenergetic peak to

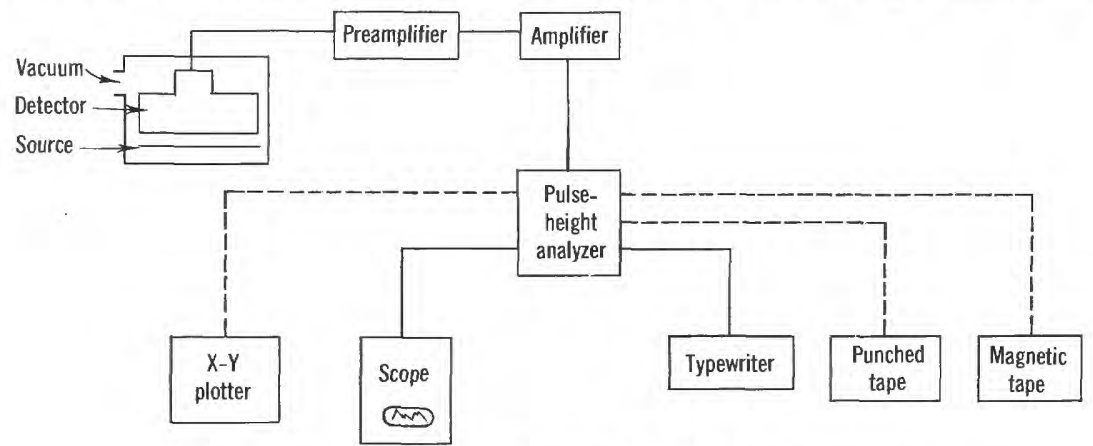

Figure 2.-Schematic diagram of alpha spectrometer. 


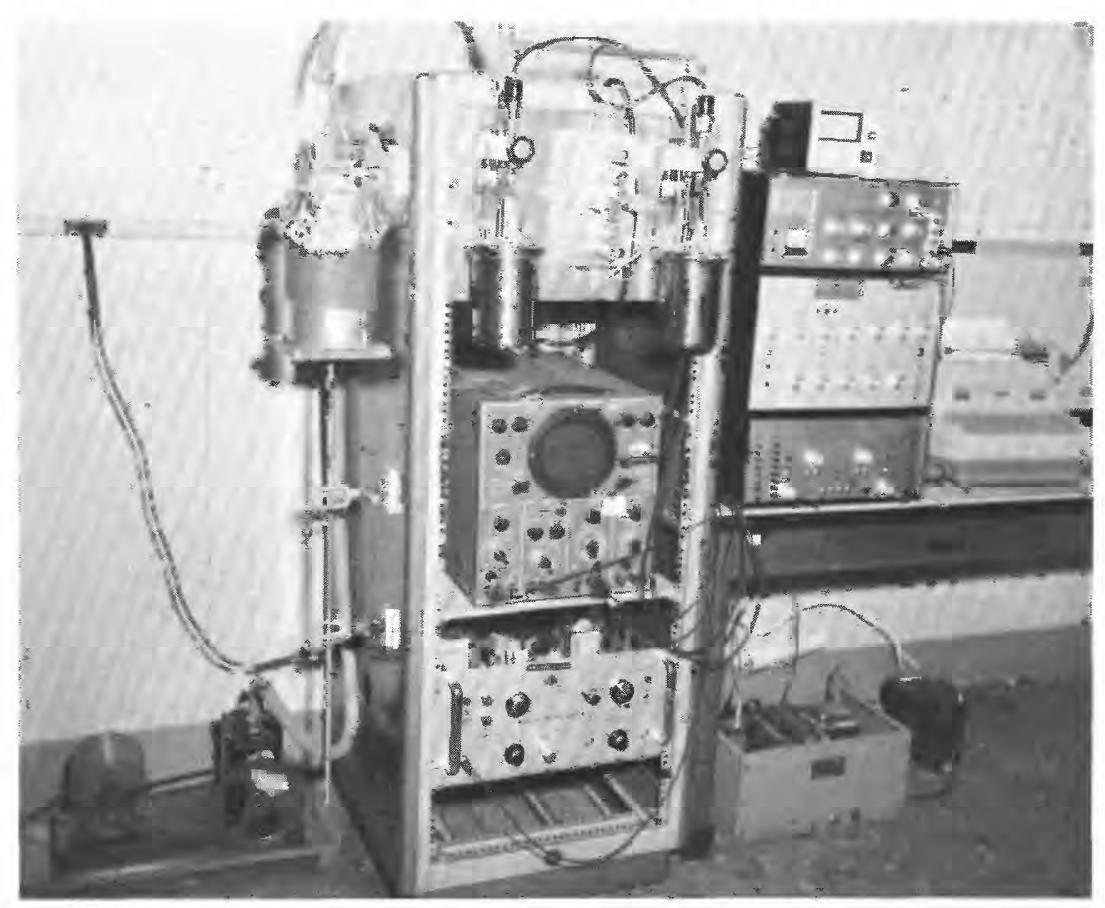

Figure 3.-Alpha spectrometer.

the peak energy. Both the FWHM and source energy must be expressed in the same units (Mev), and the ratio is usually multiplied by 100 to express it as a percent. The resolution varies with the size of the detector, the temperature of operation, and other factors, but it is nearly independent of the energy of the radiation measured. The detector used for much of the present work had a resolution of 0.7 percent for $5.305 \mathrm{Mev}$ alpha particles from polonium-210 under our experimental conditions. The apparent resolution of uranium peaks was 1.2 percent or larger because the isotopes are not monoenergetic sources, and the thickness and diameter of the deposits are much greater than those of the polonium-210 standard.

\section{ELECTRODEPOSITION}

The most desirable form of a radioactive material for alpha counting is an electroplated deposit of the pure substance on a small diameter. metal disc. As noted previously, alpha particles lose energy very rapidly in passing through matter, and this loss of energy has several undesirable consequences. A thick deposit will give a nongaussian distribution of particle energies measured by the detector, resulting in a peak which is skewed to the left; that is, a peak which appears fairly sharp on the high energy edge, but is broadened on the low energy 
side. The peak is therefore more difficult to integrate with accuracy, and the chance of overlap with other peaks is increased.

It is normally desirable, for maximum resolution, for the source to be small in diameter with respect to the detector in addition to being thin. Other factors being equal, a small diameter deposit will give both maximum counting efficiency and the best resolution. In the special case of uranium, however, the specific activity (disintegration rate per unit weight) is so small that a small diameter deposit is either too thick or contains so little uranium that the counting rate is very low. It has therefore been found preferable in this work to use a deposit having an area approximately equal to that of the detector.

A simple and direct procedure for obtaining a thin, uniform deposit of uranium is electrodeposition of the oxide, $\mathrm{U}_{3} \mathrm{O}_{8}$, on a metal-disc cathode. This deposition takes place when a weakly acidic solution of a uranyl salt is electrolyzed under moderately forcing conditions. Reduction of hydrogen ion at the cathode generates the basic condition at the electrode surface which is necessary for the deposition to take place. A variety of metals (platinum, titanium, stainless steel, nickel) was found to be satisfactory for cathodes; but titanium was used because of slightly higher recovery than on stainless steel, less corrosion than with nickel, and it is much more economical than platinum. Some other metallic oxides and free metals will codeposit with uranium if they are present in the final plating solution. Since codeposition of any material will adversely affect the resolution and counting efficiency, it is necessary that the uranium be virtually free of impurities when the electrodeposition is performed.

\section{CONCENTRATION AND PURIFICATION OF URANIUM IN NATURAL WATERS}

Uranium can be conveniently concentrated from dilute aqueous solutions by coprecipitation with aluminum phosphate under weakly acidic conditions. This precipitation gives virtually quantitative carry of uranium and has the advantage of affording a residue which is free of appreciable quantities of the major cations found in natural waters. The precipitate can be easily dissolved in acid, and the uranium selectively extracted into ethyl acetate using magnesium nitrate as a salting agent. Traces of thorium, if present in the water sample, may be coprecipitated and partially coextracted. The ethyl acetate layer is therefore evaporated to dryness; the residue is taken up with $8 \mathrm{~N} \mathrm{HCl}$, and the solution placed on an anion-exchange column. Thorium is removed from the column by washing with $8 \mathrm{~N}$ $\mathrm{HCI}$, and the uranium is then eluted with $0.1 \mathrm{~N} \mathrm{HCl}$. The uranium

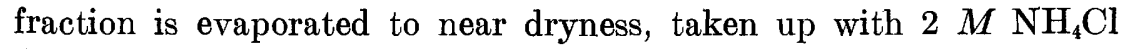
(adjusted to $\mathrm{pH}$ 2.6-3.0 with $\mathrm{HCl}$ ), and electroplated. 


\section{REAGENTS}

Reagent-grade chemicals should be used throughout.

Hydrochloric acid: $8 N$ and $0.1 N$.

Nitric acid: Concentrated.

Ammonium hydroxide: Concentrated.

Ethyl acetate.

Methyl-red indicator solution.

Titanium metal discs: 1.25 inch diameter.

Ion-exchange resin: Bio- $\mathrm{Rad} \mathrm{AG} 1-\mathrm{X} 8,50-100$ mesh.

Ammonium chloride reagent $(2.00 M, \mathrm{pH} 2.8)$ :

Dissolve $107 \mathrm{~g}$ of $\mathrm{NH}_{4} \mathrm{Cl}$ in approximately $800 \mathrm{ml}$ distilled water.

Using a $\mathrm{pH}$ meter, add dilute $\mathrm{HCl}$ dropwise until the $\mathrm{pH}$ reaches

2.7. Dilute the solution to 1 liter using a volumetric flask. Store in a polyethylene bottle.

Magnesium nitrate $(3.5 M)$-nitric acid $(1 M)$ reagent:

Fill a $500 \mathrm{ml}$ volumetric flask approximately $3 / 4$ full with distilled water and add $32 \mathrm{ml}$ of concentrated nitric acid. Mix thoroughly and add $449 \mathrm{~g}$ of $\mathrm{Mg}\left(\mathrm{NO}_{3}\right)_{2} \cdot 6 \mathrm{H}_{2} \mathrm{O}$ from a freshly opened 1pound jar. Warm gently until completely dissolved. Bring the liquid level to the mark with distilled water. Cool to room temperature and adjust the liquid volume to $500 \mathrm{ml}$.

Aluminum nitrate solution $(0.2 \mathrm{M})$.

Dissolve $7.5 \mathrm{~g}$ of high purity $\mathrm{Al}\left(\mathrm{NO}_{3}\right)_{3} \cdot 9 \mathrm{H}_{2} \mathrm{O}$ in distilled water. Add a drop of concentrated $\mathrm{HNO}_{3}$, and dilute to $100 \mathrm{ml}$.

Diammonium hydrogen phosphate solution $(0.11 \mathrm{M})$ :

Dissolve $12 \mathrm{~g}$ of diammonium hydrogen phosphate in distilled water and dilute to 1 hiter.

Ammonium nitrate solution (1 percent, w/v):

Dissolve $10 \mathrm{~g}$ of ammonium nitrate in distilled water and dilute to 1 liter.

\section{SPECIAL APPARATUS}

Beakers: Glass, 1.51 .

Beakers: Teflon, $100 \mathrm{ml}$ and $50 \mathrm{ml}$.

Funnels: Separatory, cylindrical, $60 \mathrm{ml}$ capacity with Teflon stopcocks. Columns: Ion-exchange, with teflon stopcocks. (See fig. 4.)

Centrifuge.

Centrifuge tubes: $40 \mathrm{ml}$ or $50 \mathrm{ml}$ capacity.

Steam bath or low temperature hotplate.

Alpha spectrometer:

The alpha spectrometer used in most of the work consisted of the following components:

Ortec silicon surface-barrier detector, Model SBFJ450-60, $450 \mathrm{~mm}^{2}$ sensitive area, 65-micron depletion depth at 50 volts reverse bias. 
Ortec Model 804 vacuum chamber with Hasting DV-3M thermocouple gauge tube.

W. M. Welch Duo-Seal vacuum pump capable of reducing pressure in counting chamber to less than 0.1 torr.

Liquid nitrogen cold trap. (NotE.-In subsequent work a molecular sieve foreline trap (Ion Technology, Inc., Model TR-101) was found to be simpler to use and just as effective as the liquid nitrogen trap).

Veeco vacuum gauge, No. T. E. 6 , with 5 position switching unit.

Ortec Model 101-201 low-noise amplifier system.

Multichannel pulse-height analyzer. Both a Nuclear Data Model 180D 512 channel analyzer and a Technical Measurements Corp. Model 404400 channel analyzer were used. Each was equipped with an IBM typewriter output, and the TMC analyzer also had a Tally punched tape readout.

The alpha spectrometer with the Nuclear Data analyzer is shown in figure 3.

Electroplating apparatus:

The equipment used for electrodeposition of the uranium oxide is shown in figure 5 . The cell consists of a stainless steel base with an 0.125-inch deep, 1.25-inch diameter depression for holding the titanium-disc cathode on which the uranium deposits. The vertical column is of teflon and has an outside diameter of 1.25 inches and an inside diameter of $0.875 \mathrm{inch}$. The top of the cell is an 0.5 -inch thick lucite disc with a 1.25-inch diameter by 0.125 inch deep depression to hold the column, and a 0.94-inch diameter hole through the center for insertion of the anode. The latter is a platinum wire helix suspended at a distance of approximately 0.875 inch above the titanium cathode from a polyethylene stopper. The stopper also holds a small funnel through which gases generated in the electrolysis escape, and which allows ammonium hydroxide to be added on completion of the electrodeposition. The teflon cylinder is held tightly in place and sealed both top and bottom by tightening the thumb nuts on the stainless steel rods that are attached to the base and pass through the lucite top. No gaskets are required. The pressure applied to the cathode disc by the column ensures good electrical contact between the disc and the stainless steel base. Power to the cell is provided by an Electro Products Laboratories Model D-612T filtered d-c power supply. Electrical connection to the cathode is made by a wire to a thumb screw in the base. A clip lead connects to the anode. Current is measured by a $2 \mathrm{amp}$ ammeter connected in series with the cell. 


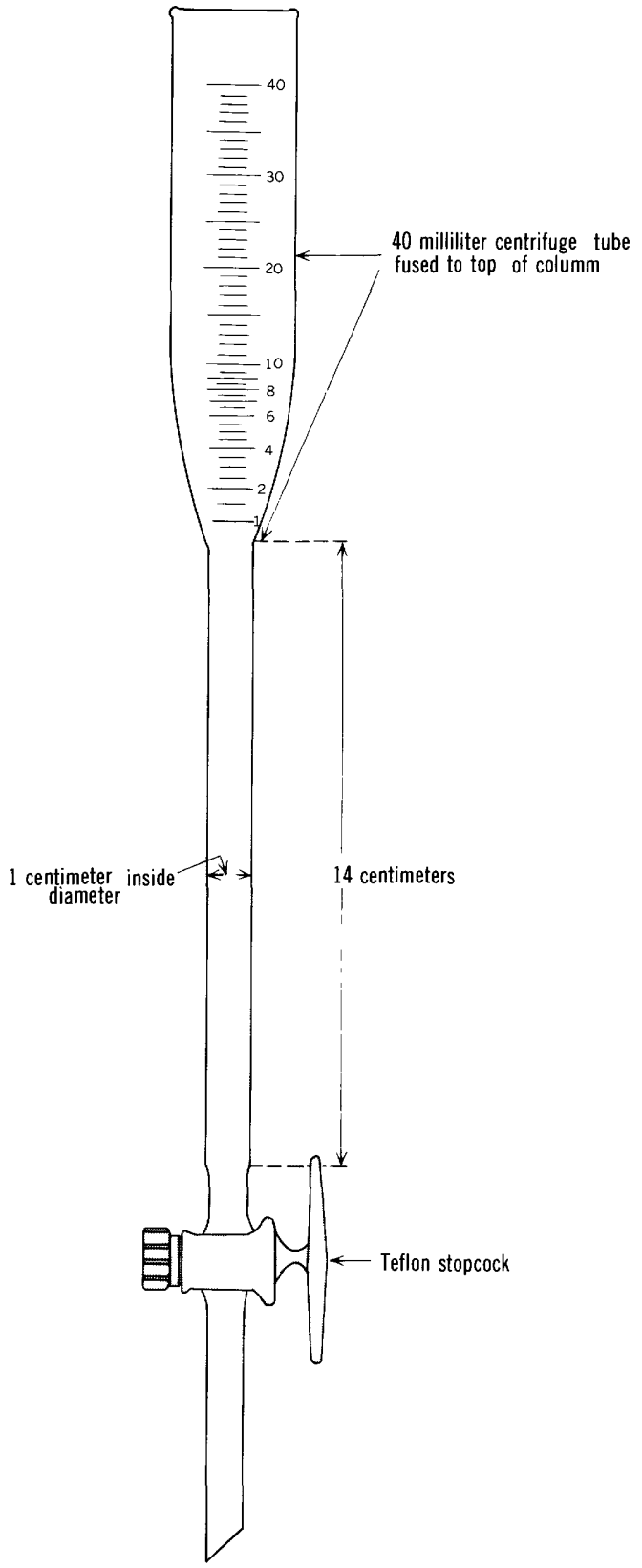

Figure 4.-Ion-exchange column. 


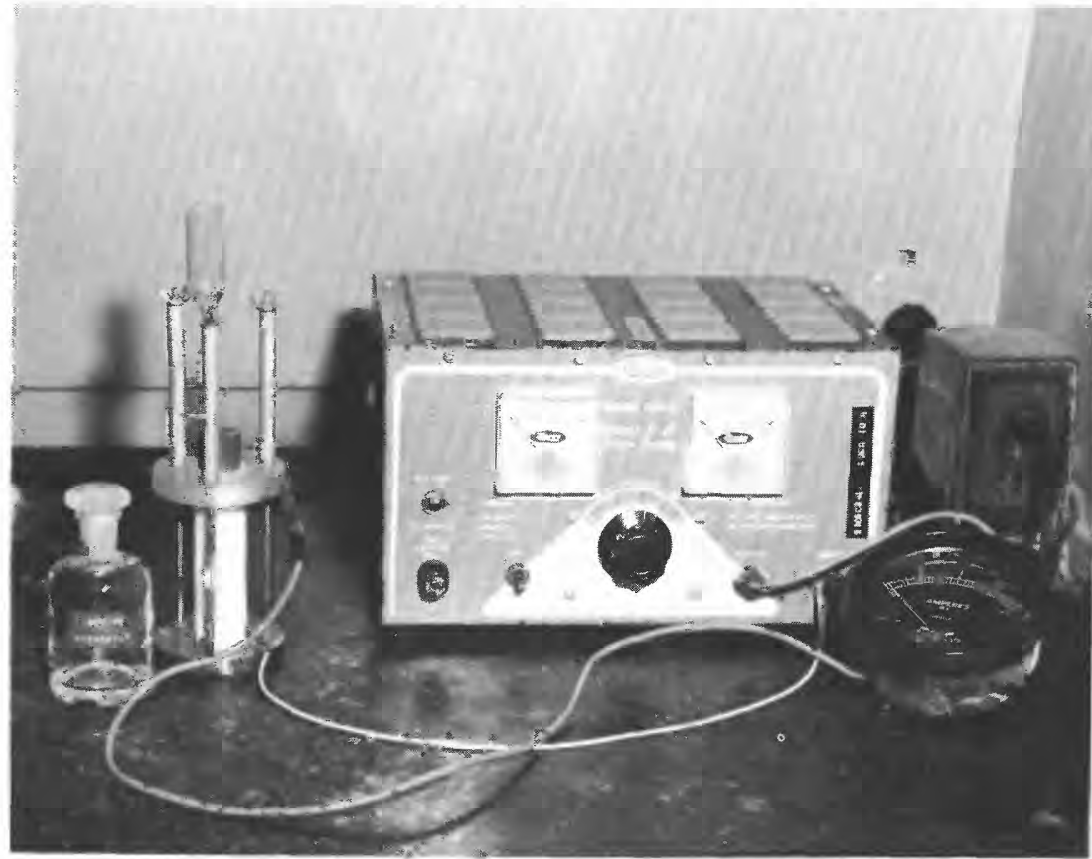

Figure 5.-Equipment for electrodeposition.

\section{PREPARATION OF ION-EXCHANGE COLUMNS}

Weigh out $6 \mathrm{~g}$ of $\mathrm{AG} 1-\mathrm{X} 8$ resin into a 50 or $100 \mathrm{ml}$ beaker. Add $15 \mathrm{ml}$ of $8 N \mathrm{HCl}$, swirl, cover with a watch glass, and allow to stand for 15 minutes or longer. Fill the lower tip of the column with water and close the stopcock. Add approx $10 \mathrm{ml}$ of $8 \mathrm{~N} \mathrm{HCl}$ to the column and add a small plug of glass wool as a resin support, using a glass rod to push it down to the bottom of the column. Slurry the resin in the beaker and pour onto the column, keeping the stopcock closed. Use an additional $5 \mathrm{ml}$ of $8 \mathrm{~N} \mathrm{HCl}$ to rinse the remaining resin out of the beaker. Allow the resin to settle by gravity. When it appears to be completely settled, draw off the $\mathrm{HCl}$ to 1 or $2 \mathrm{~cm}$ above the resin bed. Use a jet of $8 \mathrm{~N} \mathrm{HCl}$ from a wash bottle to wash down any resin adhering to the column above the resin bed and allow to settle. Add a small glass-wool plug to the top of the resin bed, being careful not to apply any pressure to the resin itself. Rinse the column with $50 \mathrm{ml} 8 \mathrm{~N} \mathrm{HCl}$, then $100 \mathrm{ml} \mathrm{H}_{2} \mathrm{O}$, and finally another $50 \mathrm{ml}$ of $8 \mathrm{~N} \mathrm{HCl}$ all at a flow rate of approx 60 drops per minute. (Note.It will be necessary to readjust the flow rate each time the eluent is changed.) Draw down the level in the column to the top of the glasswool plug. Discard the washings. The column is now ready for use. 


\section{PROCEDURE FOR ANALYSIS}

1. Determine the approximate concentration of uranium in the sample by performing a fluorimetric analysis as described in Water-Supply Paper $1696-\mathrm{C}$. If the $7 \mathrm{ml}$ volume of water called for in this procedure does not give a measurable amount of uranium, use a larger volume for the determination $(70 \mathrm{ml}$ $\max$ ).

2. Refer to table 4 to determine the sample volume to be used for the isotopic analysis. (This is based on a maximum weight of uranium in the sample of $220 \mu \mathrm{g}$ and a minimum weight of $2.5 \mu \mathrm{g}$. See notes 1 and 2, p. F16)

3 . If the sample volume used is greater than 1 liter, reduce the volume by evaporation on a hotplate as follows (note 3, p. F17):

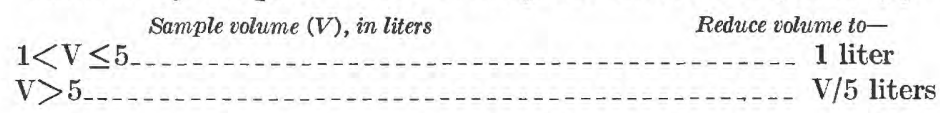

If the sample volume taken is 1 liter or less, no concentration by evaporation is required.

4. If the (reduced) volume is now 1 liter or less, proceed with step 5. If the reduced volume is greater than 1 liter, divide it into two or more approximately 1-liter subsamples in 1.5-liter beakers and perform the procedure through step 14 as if these were separate samples. After completion of the extraction of

TABLE 4.-Maximum, minimum, and recommended sample volumes for isotopic uranium analyses

\begin{tabular}{ccccc}
\hline & & \multicolumn{2}{c}{ Volume, in liters } \\
\hline $\begin{array}{c}\text { U concentration, } \\
\mu \mathrm{g} / \mathrm{M}\end{array}$ & $\begin{array}{c}\text { Maximum } \\
\text { (note 1, p. F16) }\end{array}$ & $\begin{array}{c}\text { Minimum } \\
\text { (note 2, p. F16) }\end{array}$ & Recommended & $\begin{array}{c}\text { Reduce recom- } \\
\text { mended to- }\end{array}$ \\
\hline 0.10 & 25 & 25 & 25 & 5 \\
.2 & 25 & 12.5 & 25 & 5 \\
.3 & 25 & 8.4 & 25 & 5 \\
.4 & 25 & 6.3 & 20 & 4 \\
.5 & 25 & 5.0 & 20 & 4 \\
.6 & 25 & 4.2 & 20 & 4 \\
.8 & 25 & 3.2 & 20 & 4 \\
1.0 & 25 & 2.5 & 20 & 4 \\
1.2 & 25 & 2.1 & 20 & 4 \\
1.5 & 25 & 1.7 & 20 & 3 \\
2.0 & 25 & 1.25 & 15 & 2 \\
3.0 & 25 & 0.84 & 10 & 1 \\
5.0 & 25 & .50 & 10 & 1 \\
7.0 & 25 & .36 & 5 & 1 \\
10 & 22 & .25 & 5 & 1 \\
12 & 18 & .21 & 5 & 1 \\
15 & 14 & .17 & 5 & 1 \\
20 & 11 & .13 & 2 & 1 \\
30 & 7.3 & .084 & 2 & 1 \\
50 & 4.4 & .030 & 1 & 1 \\
70 & 3.1 & .025 & 1 & \\
100 & 2.2 & & & \\
\hline
\end{tabular}


step 14, the ethyl acetate layers are combined and evaporated together.

5. To each sample (in a beaker having a volume at least 1.5 times that of the sample) add $3 \mathrm{ml}$ of concentrated $\mathrm{HNO}_{3}, 2 \mathrm{ml}$ of $0.2 M$ aluminum nitrate solution, and $5 \mathrm{ml}$ of diammonium hydrogen phosphate solution. Heat to boiling to remove any carbon dioxide.

6. Add a few drops of methyl-red indicator and neutralize to the yellow endpoint by dropwise additions of ammonium hydroxide. If, on addition of the indicator, a pink color forms and then disappears, the water probably contains excessive iodide or bromide ions. In that event, add ammonium hydroxide, 2 or 3 drops at a time; then add 1 drop of indicator. Repeat this procedure until the indicator does not turn pink upon hitting the solution but instantly exhibits the yellow color.

7. Digest the precipitate on a steam bath for 30 minutes. Allow the precipitates to cool and settle for 1 hour or longer.

8. Using a small pipet or capillary tube connected to an aspirator, draw off as much of the supernatant liquid as possible without disturbing the precipitate.

9. Transfer the precipitate to a 50-ml pyrex centrifuge tube. Police down the beaker and the stirring rod with 1 percent ammonium nitrate solution, adding the washings to the centrifuge tube. Centrifuge and discard the supernate.

10. Add $6 \mathrm{ml}$ of $3.5 M$ magnesium nitrate reagent and warm gently to dissolve the precipitate. Pour this solution into a $60 \mathrm{ml}$ cylindrical separatory funnel containing $10 \mathrm{ml}$ of ethyl acetate. Rinse the centrifuge tube three times with $3 \mathrm{ml}$ portions of magnesium nitrate solution, adding these rinse solutions to the separatory funnel.

11. Shake the separatory funnel vigorously for 2 minutes and allow 15 minutes for the layers to separate.

12. Using a pipet, draw off as much as possible of the ethyl acetate layer and transfer to a clean $50 \mathrm{ml}$ teflon beaker.

13. Add another $10 \mathrm{ml}$ of ethyl acetate to the solution in the separatory funnel and repeat step 11.

14. Draw off the ethyl acetate layer using the same pipet as used in step 12 and transfer to the teflon beaker. NoтE.-If the sample was divided in step 4, the ethyl acetate extracts should now be combined so that there is only one beaker for each sample.

15. Evaporate the solution in the teflon beaker to dryness on a steam bath. Add $10 \mathrm{ml}$ of $8 \mathrm{~N} \mathrm{HCl}$ to the beaker, cover with a watch glass, and warm on the steam bath for 10 minutes. 
16. Allow the beaker to cool to room temperature, then pour the solution on the ion-exchange column prepared as previously described. Rinse the beaker with an additional $5 \mathrm{ml}$ of $8 \mathrm{~N}$ $\mathrm{HCl}$ and add the rinse to the column.

17. Allow the liquid to flow through the column at a rate of $20-30$ drops per minute. When the level reaches the top of the resin bed, rinse the upper column with about $5 \mathrm{ml}$ of $8 N \mathrm{HCl}$, again allowing the level to drop to the top of the resin bed. Add $50 \mathrm{ml}$ of $8 \mathrm{~N} \mathrm{HCl}$ to the column and elute at the same flow rate. Discard the eluate.

18. Place a clean $100 \mathrm{ml}$ teflon beaker under the column and rinse the upper column with $5 \mathrm{ml}$ of $0.1 \mathrm{~N} \mathrm{HCl}$ from a wash bottle. When the liquid level reaches the resin bed, add $60 \mathrm{ml}$ of 0.1 $N \mathrm{HCl}$ to the column and collect the eluate at a rate of $20-30$ drops per minute.

19. Evaporate the eluate to dryness on a hotplate. Dissolve the residue in a few drops of concentrated $\mathrm{HNO}_{3}$ and evaporate on a steam bath or low temperature hotplate to about 1 drop.

20. Add $10 \mathrm{ml}$ of $2 \mathrm{M} \mathrm{NH} \mathrm{NH}_{4} \mathrm{Cl}$ solution, cover the beaker, and warm on the steam bath for 10 minutes.

21. Prepare a clean titanium disc by washing first with acetone, then with concentrated $\mathrm{HNO}_{3}$, and finally with distilled water. Assemble the electroplating cell.

22. Pour the solution from step 20 into the plating cell. Rinse the beaker twice with $5 \mathrm{ml}$ portions of plating solution and add these to the cell.

23. Electroplate the solution 100100 minutes at $1 \pm 0.1 \mathrm{amp}$ in a fume hood.

24. Loosen the stopper and cautiously pour $2 \mathrm{ml}$ of concentrated $\mathrm{NH}_{4} \mathrm{OH}$ into the cell through the funnel. Allow the plating to continue for 1 minute.

25. Remove the anode from the cell with voltage still applied. Disconnect the electrodes and turn the power supply off. Pour off the electrolyte, disassemble the cell, and rinse the plated disc thoroughly with distilled water. Flame gently till dry.

26. Count the disc for 1,000 minutes (or less if the count rate is high) on the alpha spectrometer as described in the following section.

Note 1.-A sample containing $220 \mu \mathrm{g}$ of uranium will give a deposit thickness of $50 \mu \mathrm{g}$ uranium per $\mathrm{cm}^{2}$ on the approximately $4 \mathrm{~cm}^{2}$ plating area, assuming a recovery of 90 percent. Sample volumes larger than 25 liters may be used, but are not recommended.

N оте 2. - The sample volume used should contain at least $2.5 \mu \mathrm{g}$ of uranium if a relative standard deviation of less than 10 percent in the $\mathrm{U}^{234} / \mathrm{U}^{238}$ ratio is desired using a 1,000 -minute counting time. The 
uranium concentration should therefore be $0.10 \mu \mathrm{g} / \mathrm{l}$ or greater, using a 25-liter sample, in order to obtain this accuracy. Sample volumes containing less than $2.5 \mu \mathrm{g}$ of uranium can, of course, be used if either a longer counting time or poorer accuracy can be accomodated. The $2.5 \mu \mathrm{g}$ value is calculated for an extreme case where the $\mathrm{U}^{238}$ activity is 2.5 times that of $\mathrm{U}^{234}$, the recovery is 90 percent, and the counting efficiency is 25 percent.

Note 3.-If the samples were not previously acidified, add $2 \mathrm{ml}$ of concentrated $\mathrm{HNO}_{3}$ per liter of water before starting the evaporation.

\section{PROCEDURE FOR COUNTING SAMPLES}

All components of the alpha spectrometer are turned on and allowed to warm up for at least 30 minutes before use. The detector bias control on the amplifier should always be at zero when the amplifier is turned on or off. After the amplifier has warmed up, the bias voltage is slowly turned up to the detector operating voltage. This slow adjustment prevents a large surge of reverse current through the detector which might damage it. An operating bias of 50 volts was used in all work reported here, but slightly higher or lower voltages may be required with different detectors.

Liquid nitrogen is placed in the 2-liter Dewar flask around the cold trap. The main function of the trap is to condense out oil and water vapors to which the detector is rather sensitive.

The electroplated disc is placed in the vacuum chamber and centered as close as possible to the detector without touching it; the chamber is then evacuated to a pressure of $100 \mu\left(10^{-1}\right.$ torr $)$ or less. The main amplifier gain, post amplifier gain, and post amp bias are preadjusted for the desired energy range of the spectrum using the mercury pulser on the amplifier or known energy alpha sources. In the work herein reported, an energy range of about $3.8-5.3 \mathrm{Mev}$ was used for most uranium analyses, and 200 or 256 channels of analyzer memory were normally used for accumulation of the spectra. It is usually not desirable to use less than 100 or 128 channels of memory for accumulation of uranium spectra because of the possibility of increased errors in integration of a small number of channels.

The analyzers used are constructed so that the memory can be divided into as many as four equal channel memory groups. It is possible, then, to accumulate as many as four spectra simultaneously if external detector and amplification circuitry is adequate. By so doing, maximum utilization of the rather expensive analyzer is possible, and the cost of analyses is minimized.

Because of the low uranium content of most water samples, the activity of the electroplated deposits is low and a long counting time is necessary to obtain good accuracy in $\mathrm{U}^{234} / \mathrm{U}^{238}$ ratios (tables 1,2 ). 
A preset counting time of 1,000 minutes is therefore recommended for most samples. Where such accuracy is not required or the sample is of high activity, shorter counting times may be used. After accumulation of the spectrum, the data are printed out on an IBM typewriter or other data transcriber.

\section{ANALYSIS OF THE SPECTRA}

The digital data from the IBM typewriter readout are point plotted on linear coordinate paper, and a smooth curve through the data is hand drawn. Experimental peak heights are obtained from the graphs, and the boundaries of integration of each peak are determined by the points at which the curves cross 10 percent of the number of counts at the peak maxima. Channels within these boundaries are then summed to determine the peak areas and hence the number of counts of each isotope. Channels outside the graphical peak boundary having greater than 10 percent of the peak maximum counts are not included in the summation, but channels within the boundaries with counts less than this number are included.

If resolution appears poor or marginal, the resolution of the $\mathrm{U}^{234}$ peak should be determined by dividing the FWHM in Mev by the energy of the peak. If the ratio is greater than 0.02 , the data should be discarded and a thinner deposit plated.

\section{RESULTS}

The efficiency of recovery of uranium by this method is shown in table 5 . The recoveries are very satisfactory for volumes of 1 liter or less, but they are noticeably lower for volumes greater than 1 liter. TABLE 5.-Recovery of uranium standards carried through entire chemical and electrochemical procedure

[Volume: Samples 274 and 275 , in milliliters; remainder, in liters]

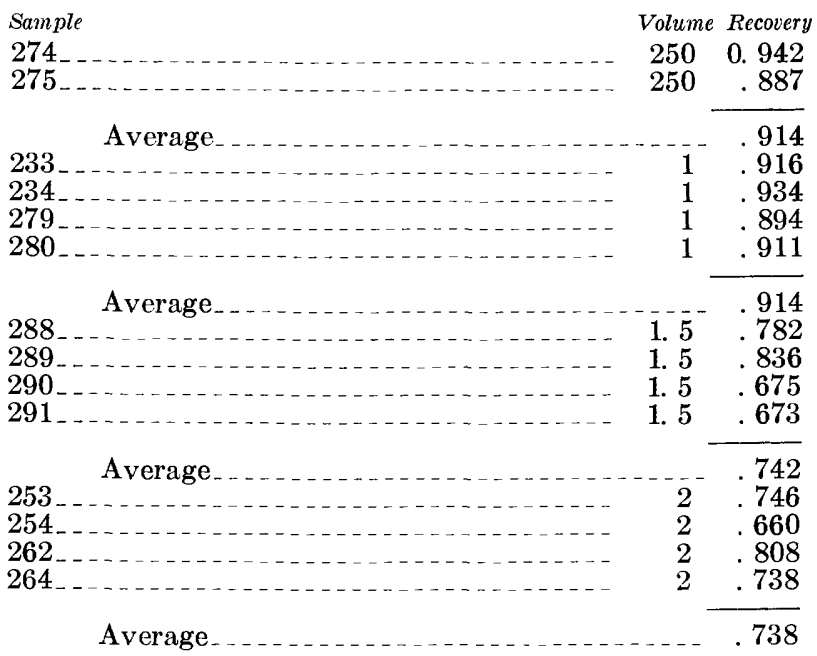


Sample volumes should therefore be reduced to 1 liter before precipitation. It is generally not desirable to reduce sample volumes to less than 20 percent of the original volume. A greater reduction in volume frequently leads to formation of undesirable precipitates which must be removed by filtration or centrifugation. When sample volumes greater than 5 liters are used, the evaporation is carried out to obtain two or more 1-liter sample concentrates. Duplicate precipitations are carried out on these, but they are later recombined for electrodeposition. Better recovery and lower reagent blanks are achieved this way over those obtained by precipitating aluminum phosphate from larger volumes.

The reagent blanks are very small, as shown in table 6 , but for lowactivity samples a correction should be made. Contribution of the blank to the statistical error of the method is covered in the following section.

TABLE 6.-Isotopic uranium blanks run on distilled water samples [Volume: Samples 276 and 277, in milliliters; remainder, in liters]

\begin{tabular}{|c|c|c|c|c|}
\hline Sample & Volume & $\mathrm{U}^{238} \mathrm{Cpm}$ & $\mathrm{U}^{234} \mathrm{Cpm}$ & Gross U Cpm \\
\hline $\begin{array}{l}276 \ldots \\
277 \\
265 \\
278\end{array}$ & $\begin{array}{r}250 \\
250 \\
1 \\
1\end{array}$ & $\begin{array}{r}0.012 \\
.012 \\
.020 \\
.003\end{array}$ & $\begin{array}{l}0.011 \\
.008 \\
.019 \\
.003\end{array}$ & $\begin{array}{r}0.023 \\
.020 \\
.039 \\
.006\end{array}$ \\
\hline Average $_{-}$ & - & .012 & .010 & .022 \\
\hline $\begin{array}{l}286 \ldots \\
287 \\
255 \\
256\end{array} 25$ & $\begin{array}{r}\text { 1. } 5 \\
1.5 \\
2 \\
2\end{array}$ & $\begin{array}{l}.008 \\
.070 \\
.031 \\
.181\end{array}$ & $\begin{array}{l}.022 \\
.035 \\
.023 \\
.099\end{array}$ & $\begin{array}{l}.031 \\
.105 \\
.054 \\
.290\end{array}$ \\
\hline
\end{tabular}

Thorium isotopes $\left(\mathrm{Th}^{230}\right.$ and $\mathrm{Th}^{232}$ ) are of major concern from the standpoint of spectral interference in uranium analyses. The procedure must therefore allow for a clean separation of this element. Using $\mathrm{Th}^{228}$ as a tracer, the thorium recovery was found to average 0.22 percent for the complete procedure. Since thorium activities are much lower than those of uranium in most natural waters, this degree of purification is generally satisfactory.

Because of the low specific activity of uranium, either a fairly heavy deposit or a long counting time will be required to obtain good statistical accuracy. Generally speaking, the uranium deposit should be as thick as possible without causing poor resolution due to loss of energy or alpha particles within the sample before they strike the detector. The variation of resolution with sample thickness is shown in figure 6 . Optimum resolution is obtained with samples having a thickness of $24 \mu \mathrm{g}$ of uranium per $\mathrm{cm}^{2}$, or less. A sample of this thickness would 


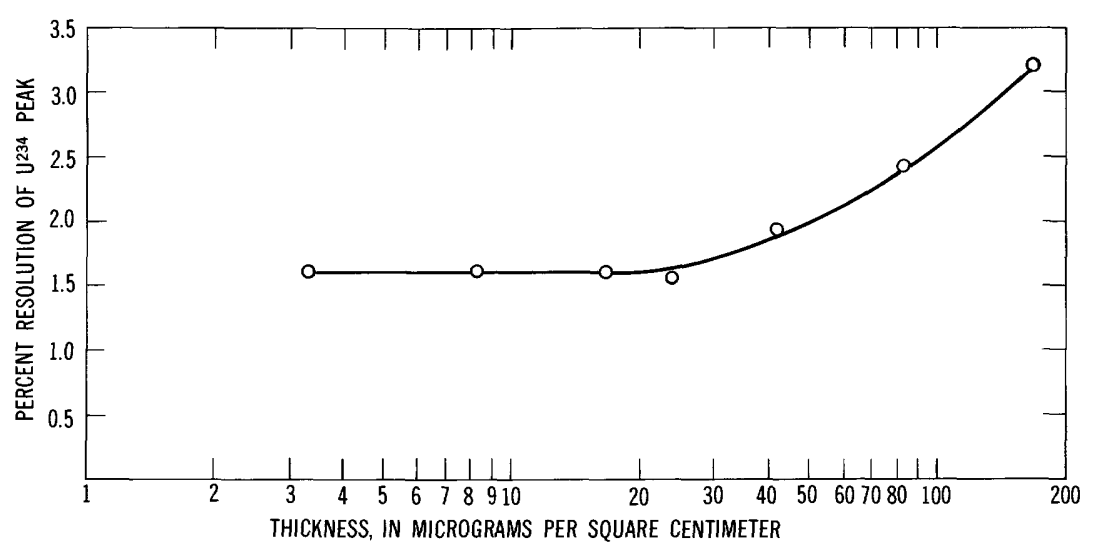

Figure 6.-Effect of source thickness on resolution of uranium alpha spectra.

give a count rate of $17.7 \mathrm{cpm}$ (counts per minute) for each isotope (assuming equilibrium) with a $4 \mathrm{~cm}^{2}$ disk and a typical counting efficiency of $0.25 \mathrm{cpm} / \mathrm{dpm}$. This would require a counting time of at least 11.3 minutes to obtain a relative standard deviation of 10 percent in the $\mathrm{U}^{234} / \mathrm{U}^{238}$ ratio, at least 47 minutes for 5 -percent error, and at least 1,130 minutes for a 1-percent standard deviation. Since the time required for good accuracy is rather long, it is sometimes desirable to use a thicker deposit and sacrifice somewhat on the resolution. It has been found that the $U^{234} / U^{238}$ ratio is reliable when the $U^{234}$ resolution is numerically less than about 2 percent. The thickness of the final deposit is therefore limited to a maximum of $50 \mu \mathrm{g}$ of uranium per $\mathrm{cm}^{2}$. At greater thicknesses it is either impossible to integrate the spectral peaks as described, or a somewhat low value for the $U^{234} / U^{238}$ ratio is obtained. Use of different integration boundaries (that is, channels where the curve crosses 20 percent of the peak maximum) also results in erroneous values of the ratio for thick deposits. The upper limit of the amount of uranium which can be plated is actually of little concern on most natural waters because of the low concentrations of uranium present.

Resolution is also affected by factors other than sample thickness. The pressure in the vacuum counting chamber must be considered because the alpha particles traverse a small air gap between the source and the detector. In the present counting system this distance is approximately $3 \mathrm{~mm}$. Under these conditions, no change in resolution was detected at pressures as high as $500 \mu$ (0.5 torr), although a slight shift in the position of uranium peaks to lower channels was noted between $100 \mu$ and $500 \mu$. At approximately $620 \mathrm{~mm}$ pressure, the peak width (FWHM) was found to be about three times as great 
as at $500 \mu$ for the same source. Thus, some evacuation of the counting chamber is necessary, but an expensive vacuum system is not required. A standard low cost mechanical pump was found sufficient to reduce pressures to $10 \mu-20 \mu$, much lower than is actually needed.

Resolution is also dependent upon the size of the detector. For optimum resolution and minimum cost, the detector should be as small as consistent with the activity (and therefore the area) of the uranium deposits. Optimum resolution is seldom required, however, and a detector having a sensitive area of $450 \mathrm{~mm}^{2}$ has been found to be a good general purpose device. With this size detector, uranium deposits as much as $200 \mu \mathrm{g}$ (at $50 \mu \mathrm{g} / \mathrm{cm}^{2}$ ) can be used.

The counting efficiency, and hence the $\mathrm{U}^{234} / \mathrm{U}^{238}$ isotopic ratio, and the average resolution were found to be virtually independent of the total number of counts providing resolution is below 2 percent. This is shown in table 7 for different counting times on a single sample. Small variations in resolution were noted from one count to another, but this did not affect the counting efficiency.

A comparison of $\mathrm{U}^{234} / \mathrm{U}^{238}$ ratios obtained by alpha spectrometry with values obtained by mass spectrographic analysis is shown in table 8. Agreement was generally found to be within one standard

TABLE 7.-Efficiency and resolution as a function of number of counts. Sample 183-61

\begin{tabular}{|c|c|c|c|c|c|c|}
\hline \multirow{2}{*}{ Spectrum } & \multicolumn{2}{|c|}{ Counts } & \multicolumn{2}{|c|}{ Efficiency } & \multicolumn{2}{|c|}{ Resolution } \\
\hline & $\mathrm{U} 234$ & $\mathrm{U}^{238}$ & $\mathrm{U}^{234}$ & $\mathrm{U}^{238}$ & $\mathrm{U}^{234}$ & $\mathrm{U}^{238}$ \\
\hline $\begin{array}{l}97 \ldots \ldots \\
122 \ldots \ldots\end{array}$ & $\begin{array}{l}11,237 \\
10,181\end{array}$ & $\begin{array}{l}11,693 \\
10,382\end{array}$ & $\left.\begin{array}{l}23.0 \\
22.7\end{array}\right\} 22.8$ & $\left\{\begin{array}{l}23.3 \\
22.5\end{array}\right\} 22.9$ & $\left\{\begin{array}{l}1.63 \\
1.60\end{array}\right\} 1.62$ & $\left\{\begin{array}{l}1.67 \\
1.85\end{array}\right\} 1.76$ \\
\hline $\begin{array}{l}87 \\
89 \\
91 \\
93 \\
95\end{array}$ & $\begin{array}{l}1,610 \\
1,599 \\
1,613 \\
1,590 \\
1,593\end{array}$ & $\begin{array}{l}1,630 \\
1,624 \\
1,685 \\
1,616 \\
1,632\end{array}$ & $\left.\begin{array}{l}23.4 \\
23.2 \\
23.4 \\
23.1 \\
23.2\end{array}\right\} 23.3$ & $\left\{\begin{array}{ll}23 . & 1 \\
23 . & 0 \\
23 . & 9 \\
22 . & 9 \\
23 . & 1\end{array}\right\} 23.2$ & $\left\{\begin{array}{l}1.48 \\
1.71 \\
1.57 \\
1.48 \\
1.78\end{array}\right\} 1.60$ & $\left\{\begin{array}{l}1.99 \\
1.81 \\
1.71 \\
1.76 \\
1.71\end{array}\right\} 1.80$ \\
\hline $\begin{array}{l}102 \ldots \\
107 \ldots \\
110 \\
113 \\
116 \ldots \\
123\end{array}$ & $\begin{array}{l}621 \\
649 \\
673 \\
600 \\
631 \\
618\end{array}$ & $\begin{array}{l}640 \\
643 \\
627 \\
662 \\
649 \\
663\end{array}$ & $\left.\begin{array}{l}22.6 \\
23.6 \\
24.4 \\
21.8 \\
22.9 \\
22.1\end{array}\right\} 22.9$ & $\left\{\begin{array}{l}22.7 \\
22.8 \\
22 . \\
23.4 \\
23.0 \\
23.5\end{array}\right\} 22.9$ & $\left\{\begin{array}{l}1.60 \\
1.60 \\
1.45 \\
1.64 \\
1.64 \\
1.51\end{array}\right\} 1.57$ & $\left\{\begin{array}{l}1.82 \\
1.93 \\
1.74 \\
1.90 \\
1.81 \\
1.78\end{array}\right\} 1.83$ \\
\hline $\begin{array}{l}99 \\
100 \\
101 \\
103 \\
104 \\
105 \\
108 \\
109 \\
112 \\
115\end{array}$ & $\begin{array}{l}183 \\
150 \\
157 \\
163 \\
162 \\
157 \\
168 \\
156 \\
171 \\
162\end{array}$ & $\begin{array}{l}155 \\
162 \\
162 \\
187 \\
162 \\
161 \\
163 \\
170 \\
156 \\
171\end{array}$ & $\left.\begin{array}{l}26.6 \\
21.8 \\
22.8 \\
23.7 \\
23.5 \\
22.8 \\
24.4 \\
22.7 \\
24.9 \\
23.6\end{array}\right\} 23.7$ & $\left\{\begin{array}{ll}21 . & 2 \\
22 . & 9 \\
22 . & 7 \\
26 . & 5 \\
22 . & 9 \\
22 . & 8 \\
23 . & 1 \\
24 . & 1 \\
22 . & 1 \\
24 . & 2\end{array}\right\} 23.3$ & - & $\begin{array}{c}- \\
- \\
-\end{array}$ \\
\hline
\end{tabular}


deviation of the statistical counting error. The errors in the mass spectrographic data should be very small, and the ratios obtained by this method are taken to be the true values. Duplicate analyses of most samples by alpha spectrometry show good reproducibility.

Isotopic ratios for several eastern slope Colorado streams are shown in table 9. These streams were all found to have an excess of $\mathrm{U}^{234}$ but quite a large range of ratios were observed.

TABLE 8.- $\mathrm{U}^{234} / \mathrm{U}^{238}$ activity ratios as determined by mass spectrometry and alpha spectrometry

\begin{tabular}{|c|c|c|}
\hline \multirow{2}{*}{ Source } & \multicolumn{2}{|c|}{$\mathrm{U}^{234 / \mathrm{U}^{238} \text { ratios }}$} \\
\hline & $\begin{array}{c}\text { Mass } \\
\text { spectrometry }\end{array}$ & $\begin{array}{l}\text { Alpha } \\
\text { spectrometry }\end{array}$ \\
\hline Congo standard & 1. 000 & $\begin{array}{l}0.994 \pm 0.02 \\
\text { 1. } 008 \pm .03 \\
\text { 1. } 002 \pm .02\end{array}$ \\
\hline Ore $301711 \ldots$ & $\begin{array}{l}4197 \\
.4123\end{array}$ & $\begin{array}{l}.411 \pm .010 \\
.419 \pm .006 \\
.403 \pm .011\end{array}$ \\
\hline $301713 \ldots \ldots \ldots \ldots \ldots$ & 4552 & $\begin{array}{l}.444 \pm .009 \\
.467 \pm .008\end{array}$ \\
\hline Unknown origin & 1. 39 & $\begin{array}{l}\text { 1. } 46 \pm .03 \\
\text { 1. } 39 \pm .03 \\
\text { 1. } 37 \pm .03 \\
\text { 1. } 42 \pm .05\end{array}$ \\
\hline
\end{tabular}

TABLE 9.- $\mathrm{U}^{234} / \mathrm{U}^{238}$ ratios of eastern slope streams in Colorado

\begin{tabular}{|c|c|c|c|c|}
\hline Source & Date sampled & $\begin{array}{c}\text { Volume } \\
\text { collected } \\
\text { (liters) }\end{array}$ & $\begin{array}{c}\mathrm{U}^{238} \text { con- } \\
\text { centration } \\
\mu \mathrm{g} / 1\end{array}$ & $\mathrm{U}^{234} / \mathrm{U}^{238}$ \\
\hline Big Thompson River & Apr $\stackrel{1966}{7}$ & & & $1.38+0.10$ \\
\hline South St. Vrain Creek & Mar. 24 & 30 & 1.1 & 1. $67 \pm .07$ \\
\hline Left Hand Creek $\ldots$ & $\ldots$ do ....... & 20 & 7. 2 & 1. $05 \pm$ \\
\hline Clear Creek & Mar. 3 & 50 & 1. 8 & 1. $14 \pm$ \\
\hline & Mar. 11_... & 40 & 2. 1 & 1. $18 \pm .02$ \\
\hline Bear Creek & Apr. 5 $\ldots$ & 20 & 2.4 & 1. $53 \pm$ \\
\hline
\end{tabular}

\section{DISCUSSION}

Alpha spectrometry appears to be a highly satisfactory method for the isotopic analysis of uranium present in natural waters. The procedure described separates uranium from bulk impurities which add to the thickness of the final deposit causing poor resolution and from radiochemical impurities which cause spectral interference and resultant counting errors.

Of the radionuclides which have alpha energies sufficiently close to those of the uranium isotopes to cause errors, only thorium appears to be of consequence in natural waters. Radium-226 has alpha energies 
which would interfere if this nuclide were present in the final deposit, but radium is an active metal and does not electroplate under the conditions described. Protactinium-231 emits alphas of several different energies and is a potential interference in the analysis. Although detailed interference tests have not been made, no natural waters so far analyzed have been found to give detectable amounts of this nuclide in the final deposit. Protactinium is expected to behave similarly to uranium in the chemical separations of this procedure, and its absence in the final electrodeposits prepared from natural water samples is probably an indication of its absence in the original sample. Eighty-four percent of the $\mathrm{Pa}^{231}$ alpha-particle energies are in the range 4.92 to $5.05 \mathrm{Mev}$. These are sufficiently above the $\mathrm{U}^{234}$ energies to be clearly distinguishable, although some overlap will occur. Where slight $\mathrm{Pa}^{231}$ activity is found, the spectral overlap may be approximated and a correction made. If relatively high interference occurs, a chemical separation may be necessary.

Actinium-227 also has an alpha energy (4.94 Mev) sufficiently close to that of $U^{234}$ to cause interference if present in large amounts in the final deposit. Separation of this nuclide should be good, however, since actinium is not absorbed on the ion-exchange column. Furthermore, $\mathrm{Ac}^{227}$ decays only 1.2 percent by alpha emission; interference, therefore, should be negligibly small.

The method of plotting and integrating the spectra is somewhat tedious, but the time involved is small compared to that of the chemical procedure and improved results justify its use. Point plotting of the data may be done by either hand or an X-Y plotter, but the spectrum should be hand drawn. A smooth curve through the data allows a more accurate determination of the peak height and the boundaries of integration. The accuracy of the integrals, and hence the isotopic ratio, are therefore improved. Use of predetermined channel intervals for integration was found to be unsatisfactory because of drift in the detection and analysis system during long counting periods and because of variation in the resolution from one sample to another.

Tables 1 and 2 give the statistical error in $\mathrm{U}^{234} / \mathrm{U}^{238}$ ratios in the final deposit under interference-free conditions. These data were calculated from the equation:

$$
\frac{\sigma_{R}}{R}=\left(\frac{\sigma_{234}^{2}}{C_{234}^{2}}+\frac{\sigma_{238}^{2}}{C_{238}^{2}}\right)^{1 / 2}
$$

where $\sigma_{R}$ is the standard deviation of the activity ratio, $R$, of $\mathrm{U}^{234} / \mathrm{U}^{238}$, $\sigma_{234}$ and $\sigma_{238}$ are the standard deviations of the number of counts, $C^{234}$ and $C^{238}$, of the two isotopes. With the assumption that 
the standard deviation of each count is equal to the square root of the number of counts, equation 1 reduces to

$$
\frac{\sigma_{R}}{R}=\left(\frac{1}{C_{234}}+\frac{1}{C_{238}}\right)^{1 / 2}
$$

This equation is valid if the number of counts of each isotope is 100 or greater, but it leads to errors for lower total counts. The assumption is also made that the detector background is negligibly small. The gross uranium background for the detector was found to average $0.004 \mathrm{cpm}(0.002 \mathrm{cpm}$ for each isotope), and neglect of this quantity is therefore quite acceptable.

The isotopic ratio as measured by the alpha spectrometer is correct, within the limitations of counting statistics, for the uranium on the disc. This is not necessarily the true value for the uranium in the original sample because of uranium contributed by reagents in the chemical procedure. Blank runs, as shown in table 6 , gave an average uranium count rate of $0.022 \mathrm{cpm}$ for sample volumes of 1 liter or less. Although this is small, it may be sufficient to cause error in the isotopic ratio for low-activity samples. The statistical error should therefore be larger than the values shown in tables 1 and 2 .

If the gross counts for the sample are designated by $A$, the mean reagent blank plus detector background by $B$, and the net ("true") sample counts by $C$,

and

$$
C=A-B
$$

$$
\sigma_{C}^{2}=\sigma_{A}^{2}+\sigma^{2}{ }_{B}
$$

so that, from equation 1

$$
\frac{\sigma_{R}}{R}=\left(\frac{\sigma_{A_{234}}^{2}+\sigma_{B_{234}}^{2}}{C_{234}^{2}}+\frac{\sigma_{A_{238}}^{2}+\sigma_{B_{238}}^{2}}{C_{238}^{2}}\right)^{1 / 2} .
$$

If it is now assumed that the number of observed counts of each isotope is greater than 100 ,

$$
\begin{gathered}
\sigma_{A_{234}}^{2}=A_{234} \\
\sigma_{A_{238}}{ }^{2}=A_{238} .
\end{gathered}
$$

Since the blanks are small $(B<100)$ and $B_{234} \cong B_{238}=B$, the error in this count is approximated by

$$
\sigma^{2}{ }_{B}=B+1 \text {. }
$$


Then the relative standard deviation in the ratio is

$$
\frac{\sigma_{R}}{R}=\left(\frac{A_{234}+B+1}{\left(A_{234}-B\right)^{2}}+\frac{A_{238}+B+1}{\left(A_{238}-B\right)^{2}}\right)^{1 / 2},
$$

and the absolute standard deviation is given by

$$
\sigma_{R}=R\left(\frac{A_{234}+B+1}{\left(A_{234}-B\right)^{2}}+\frac{A_{238}+B+1}{\left(A_{238}-B\right)^{2}}\right)^{1 / 2} .
$$

When $A>>B$, equation 3 reduces to equation 2 .

Equations 3 and 4 should normally be used for calculation of the error in isotopic ratios unless the sample activity is high or the blank is very small. Blanks should be redetermined each time any of the reagent batches are changed. Care should also be exercised to note that the total blank is the blank per precipitation multiplied by the number of precipitates for each sample which are combined, after extraction, to give the final uranium deposit.

\section{ACKNOWLEDGMENT}

The author wishes to express his appreciation to Dr. John Rosholt, of the Isotope Geology Branch, Geologic Division, U.S. Geological Survey, for use of equipment in part of this study and for furnishing standards and to Mrs. Marjorie Rickard for performance of much of the chemical laboratory work.

\section{REFERENCES}

Ancarani, L., and Bettinali, C., 1960, Analisi isotopica dell-uranio e dello zolfo nello studio delle mineralizzazioni di Canale Monterano, in Studi e Ricerche della Divsione Geomineraria, v. 3: Comitato Nazionale per le Ricerche Nucleari, Roma, p. 1-22.

Atomics, 1964, U-235 content of natural uranium: Atomics, v. 17, no. 6, p. 55.

Barker, F. B., Johnson, J. O., Edwards, K. W., and Robinson, B. P., 1965, Determination of uranium in natural waters: U.S. Geol. Survey Water-Supply Paper 1696-C, $25 \mathrm{p}$.

Cathey, L., 1961, Low level alpha counting with solid state detectors: IRE Transactions on Nuclear Sci., NS-8, no. 4, p. 10-15.

Chalov, P. I., Tuzova, T. A., and Musin, Ya. A., 1964, Isotopic ratio of U ${ }^{234} / \mathrm{U}^{238}$ in natural waters and utilization of the ratio in nuclear geochronology: Izv. Akad. Nauk SSSR, Ser. Geofiz, no. 10, p. 1552-61.

Cherdyntsev, V. V., Kozachevskii, I. V., and Kuzmina, E. A., 1963, Isotopic composition of uranium and thorium in the zone of hypergenesis. Investigation of fossil bones, soil, and shells of mollusks: Geokhimiya, no. 3, p. 254-65.

- 1965, Age of Pleistocene carbonate formation according to thorium and uranium isotopes: Geokhimiya, no. 9, p. 1085-92.

Cherdyntsev, V. V., Orlov, D. P., Isabaev, E. A., and Ivanov, V. I., 1961, Isotopes of uranium in natural conditions. II. Isotopic composition of uranium in minerals: Radiokhimiya, no. 10 , p. 840-848. 
Donovan, P. F., 1962, Semiconductor particle detectors: Annual Rev. Nuclear Sci., v. 12, p. 189-220.

Dooley, J. R., Jr., Tatsumoto, M., and Rosholt, J. N., 1964, Radioactive disequilibrium studies of roll features, Shirley Basin, Wyoming: Econ. Geology, v. 59 , p. $586-595$.

Isabaev, E. A., Usatov, E. P., and Cherdyntsev, V. V., 1960, Isotopic composition of uranium in nature: Radiokhimiya, no. 2, p. 94-97.

Katz, J. J., and Rabinowitch, E., 1951, Chemistry of uranium: New York, McGraw-Hill, 609 p.

Nucleonics, 1962, Semiconductors, scintillators and pulse-height analyzers: Nucleonics, v. 20 , no. 5 , p. 53 .

1964, New developments in nuclear-particle detection: Nucleonics, v. 22, no. 5 , p. 49 .

Rosholt, J. N., Butler, A. P., Garner, E. L., and Shields, W. R., 1965, Isotopic fractionation of uranium in sandstone, Powder River Basin, Wyoming, and Slick Rock District, Colorado: Econ. Geology, v. 60, p. 199-213.

Rosholt, J. N., Doe, B. R., and Tatsumoto, M., 1966, Evolution of the isotopic composition of uranium and thorium in soil profiles: Geol. Soc. America Bull., v. 77, p. $987-1004$.

Rosholt, J. N., Harshman, E. N., Shields, W. R., and Garner, E. L., 1964, Isotopic fractionation of uranium related to roll features in sandstone, Shirley Basin, Wyoming: Econ. Geology, 1964, v. 59, p. 570-585.

Rosholt, J. N., Shields, W. R., and Garner, E. L., 1963, Isotopic fractionation of uranium in sandstone: Science, v. 139, p. 224-226.

Rosholt, J. N., Tatsumoto, M., and Dooley, J. R., Jr., 1965, Radioactive disequilibrium studies in sandstone, Powder River Basin Wyoming, and Slick Kock District, Colorado: Econ. Geology, v. 60, p. 477-484.

Sakanoue, M., and Hashimoto, T., 1964, A study of ${ }^{234} \mathrm{U} /{ }^{238} \mathrm{U}$ ratio in natural samples: Nippon Kagaku Zasshi, v. 85, p. 622-627.

Strominger, D., Hollander, J. M., and Seaborg, G. T., 1958, Table of isotopes: Rev. Modern Physics, v. 30, p. 585-904.

Syromyatnikov, N. G., 1965, About use of ${ }^{234} \mathrm{U} /{ }^{238} \mathrm{U}$ isotopic ratio for interpretation of uranium anomaly: Atomnaya Energiya (USSR), v. 19, p. 169-74.

Syromyatnikov, N. G., and Tolmachev, I. I., 1962, Study of the isotopic ratio $\mathrm{U}^{234} / \mathrm{U}^{238}$ in aqueous extracts from uranium-phosphate-zirconium ores with consideration of their formation: Atomnaya Energiya (USSR), v. 13, p. 600-602.

Thurber, D. L., 1962, Anomalous $\mathrm{U}^{234} / \mathrm{U}^{238}$ in nature: Jour. Geophys. Research, v. 67, p. $4518-4520$. 

